\title{
Effects of Bovine Milk Fermented by Culturing with Lactic Acid Bacteria and a Yeast on the Proliferation Activity of Human Carcinoma Cells
}

\author{
Makoto Ito, ${ }^{1}$ Molay Kumar Roy, ${ }^{1}$ Kenji Kurihara, ${ }^{1}$ Yasuo Watanabe, ${ }^{1}$ Yuji Kuwabara, ${ }^{2}$ Seiichiro NaGAI ${ }^{2}$ \\ and Youichi TAMAI ${ }^{*}$ \\ ${ }^{1}$ Department of Bioresources, Faculty of Agriculture, Ehime University, Matsuyama, Ehime 790, Japan. \\ ${ }^{2}$ Shikoku Milk Product Co., Ltd., Kawauchi, Ehime 791-03, Japan
}

Received July 7, 1997; Accepted February 5, 1998

\begin{abstract}
The effects of aged fermented bovine milk produced by a mixture of various lactic acid bacteria and a yeast, or a mixture of the lactic acid bacterium, Bifidobacterium longum, and a yeast on the proliferation activities of human carcinoma cells (DLD-1, MKN-1, and HL-60 cell lines) and human normal fibroblast cells (Fb) were investigated. Nonfermented bovine milk suppressed the proliferation activity in various degrees depending on the cell lines tested, suggesting that bovine milk may contain a component regulating in vivo proliferation of certain cells. The fermented milk produced by a mixture of various lactic acid bacteria and a yeast selectively reduced the proliferation activity of DLD-1 and MKN-1 cells. In contrast, the fermented milk produced by a mixture of $B$. longum and a yeast was selectively toxic to HL-60 cells, and cell proliferation activity was completely lost. Analysis of this cytotoxicity was revealed to be due to the induction of apoptosis which was demonstrated by the formation of apoptotic bodies and the fragmentation of DNA in treated cells. These findings strongly suggest that the cytotoxic factors affecting the viability of transformed and nontransformed cells are present in latent form in bovine milk, and these factors could be produced from milk by digestion using microbial enzymes.
\end{abstract}

Keywords: milk, lactic acid bacteria, fermented, HL-60, apoptosis

Kefir is an aged fermented milk produced by Kefir granules in which various species of lactic acid bacteria, yeasts and some species of acetic acid bacteria co-exist (Adachi et al. 1990). Kefir is believed to contain many functional substances. Recently, the effective utilization of enzymes by combining various enzymes from different microorganisms has received attention, because such a multi-enzyme system is expected to produce novel physiologically active substances. Saccharomyces cerevisiae cannot grow in bovine milk alone, but it can grow if lactic acid bacteria are present, because lactic acid bacteria provide a source of nitrogen (amino acids) for the yeast by hydrolyzing milk proteins with proteases which they secrete (Ezzat et al. 1985; Kok 1990; Pritchard \& Coolbear 1993). In such a mixed-culture medium, it is thought that a much wider variety of substances is produced from milk components than in the case of a single-culture medium. On the basis of this, we investigated, in a previous study, a process for the manufacture of aged fermented milk using a mixture of various lactic acid bacteria and a yeast (Tamai et al. 1995). The fermented milk produced by a mixed culture of various strains of lactic acid bacteria and a yeast exhibited more effective antimutagenicity against a wider range of mutagens than milk produced using a single lactic acid bacterium. In the present study, we investigated the effect of fermented milk on the proliferation activity of human carcinoma cell lines and provided preliminary evidence of the cytotocicity of fermented milk to HL-60 cells. Prior to this study, the effects of aged fermented bovine milk produced by

\footnotetext{
* To whom correspondence should be addressed.
}

a mixture of various lactic acid bacteria and a yeast on cell proliferation had not been investigated.

\section{Materials and Methods}

Materials The cell titer 96 aqueous non-radioactive cell proliferation assay system (MTS assay system) was purchased from Promega. RPMI medium, Dulbecco's PBS $(-)$, BL-agar medium, and GAM-broth were purchased from Nissui (Tokyo). All other chemicals used were of the purest grade available.

Preparation of fermented milk Two kinds of fermented milk were prepared. One fermented milk prepared by culturing with various lactic acid bacteria and a yeast corresponded to a fermented milk No. 4 in a previous paper (Tamai et al. 1995) and was abbreviated as F.M.1 in this paper. The lactic acid bacteria used for the mixed culture were Lactococcus lactis subsp. lactis SMK 111, Lactococcus lactis subsp. cremoris SMK 118, Streptococcus lactis subsp. diactylactis SMK 413, Streptococcus salivarius subsp. thermophilus SMK 447, Leuconostoc cremoris SMK 308, Lactobacillus delbrueckii subsp. bulgaricus SMK 750, Lactobacillus casei SMK 709, and Lactobacillus helveticus SMK 745. The yeast was invertase-deficient Saccharomyces cerevisiae. All strains were from the culture collection of the Reseach Laboratory of Shikoku Milk Product Co., Ltd (Ehime). Another fermented milk was prepared with Bifidobacterium longum SMK 595 and a yeast according to the method used for preparing fermented milk No. 5 in a previous paper (Tamai et al. 1995), except that the culture temperature was $35^{\circ} \mathrm{C}$ and culture time was $14 \mathrm{~d}$. The culture temperature and time accelerated more 
growth of $B$. longum than before. This fermented milk was abbreviated as F.M.2 in this paper.

Cell cultures Human stomach carcinoma (MKN-1), human colon carcinoma (DLD-1), and human acute myeloid leukemia (HL-60) cells were obtained from the Japanese Cancer Research Resources Bank (JCRB), Tokyo. Human dermal fibroblast $(\mathrm{Fb})$ cells were purchased from Cell System Corporation (Kirkland, WA). The former cell lines were routinely cultured in RPMI 1640 medium supplemented with $10 \%$ fetal bovine serum, $0.1 \mathrm{mg} / \mathrm{ml}$ streptomycin, $100 \mathrm{U} / \mathrm{ml}$ penicillin, and $1.4 \mathrm{mg} / \mathrm{ml} \mathrm{NaHCO}_{3}$ at $37^{\circ} \mathrm{C}$ in a humidified atomosphere containing $5 \% \mathrm{CO}_{2}$. The latter were cultured in a fibroblast cell growth medium system (CS-3FO-250) at $37^{\circ} \mathrm{C}$ in a humidified atomosphere containing $5 \% \mathrm{CO}_{2}$.

Effect of fermented milks on cell proliferation activity Counting viable cells: Prior to the proliferation activity test, two kinds of fermented milk (F.M.1 and F.M.2) were adjusted to $\mathrm{pH} 7.0$ by adding a small amount of $8 \mathrm{~N} \mathrm{NaOH}$. The resulting precipitates were removed by centrifugation at $27,000 \times g$ for $10 \mathrm{~min}$. The supernatants were sterilized by filtration through filter paper $(0.45 \mu \mathrm{m})$, and $1 \mathrm{ml}$ of each was added to $9 \mathrm{ml}$ of culture media containing $10^{6}$ cells. As a control, bovine milk was supplemented with lactic acid until the $\mathrm{pH}$ of the milk reached 3.6 and then adjusted to $\mathrm{pH} 7.0$ by adding $8 \mathrm{~N} \mathrm{NaOH}$. The precipitate was removed, sterilized by filtration and used. Samples incubated in the absence of milk were also used. At 24, 48 and $72 \mathrm{~h}$ after the start of incubation, viable HL-60 cells in suspension culture were counted using the trypan blue dye exclusion method. In those cases where cells adhered to the flasks (DLD-1, MKN-1, and Fb cells), the culture supernatants were discarded, the flasks were washed twice with phosphate-buffered saline (PBS $(-))$, and the cells

\section{DLD-1}

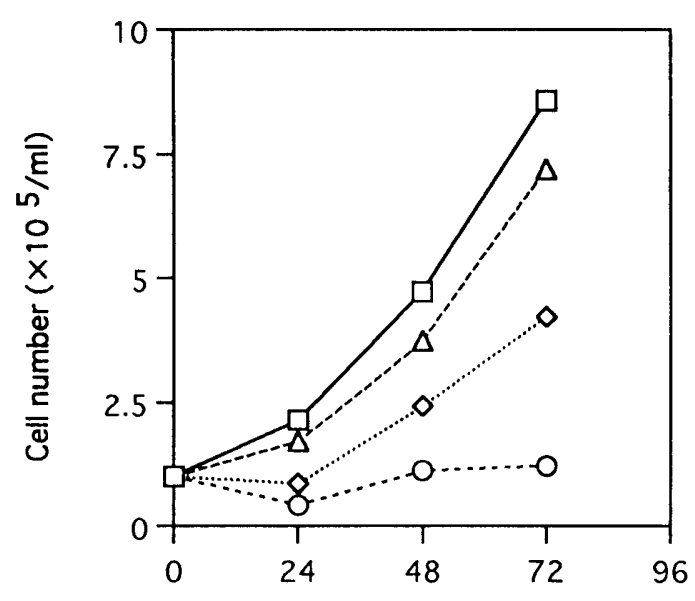

Tine (h)

\section{HL-60}

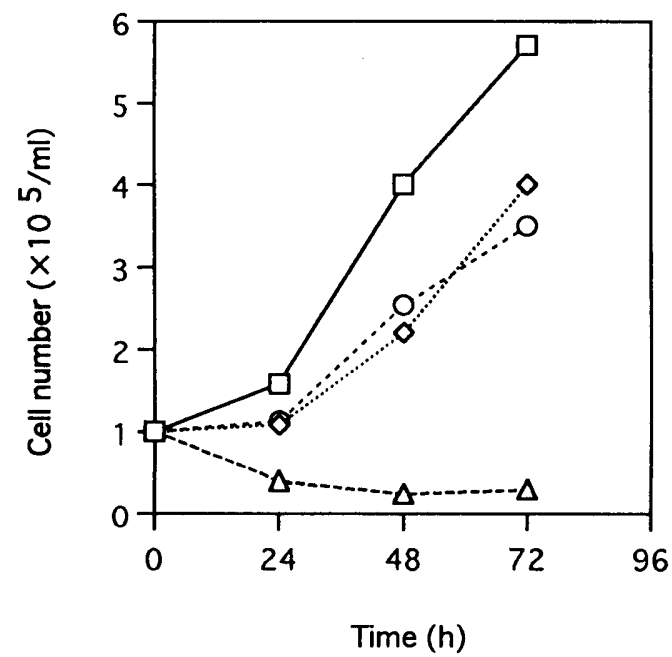

$\mathrm{MKN}-1$

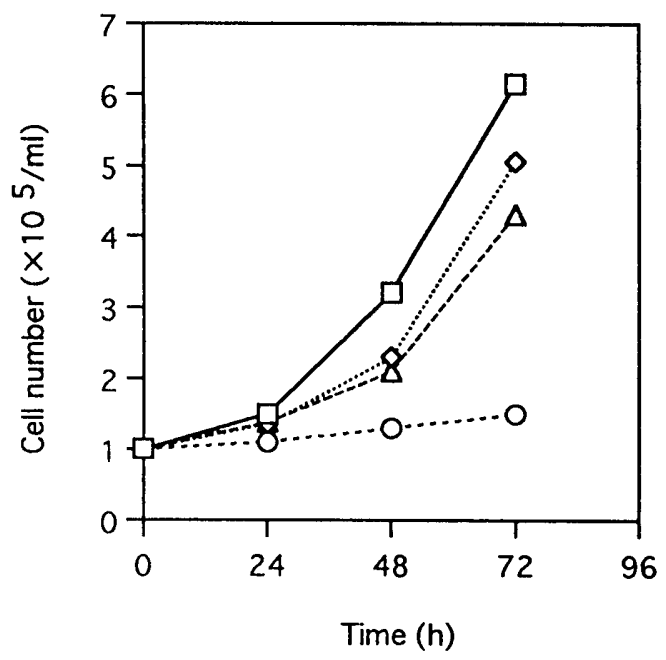

$\mathrm{Fb}$

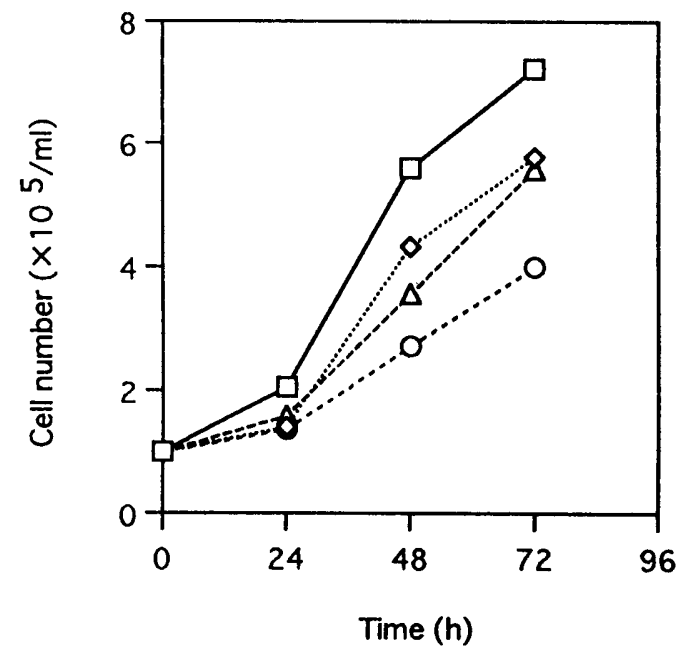

Fig. 1. Effects of milk on the growth of human transformed and nontransformed cells by counting viable cells. Human cells were cultured in the absence or presence of fermented or nonfermented bovine milk. Cells were counted at 24,48 and $72 \mathrm{~h} . \sqsupset$, in the absence of milk. $\diamond$, in the presence of nonfermented bovine milk. $\bigcirc$, in the presence of fermented milk (F.M.1). $\triangle$, in the presence of fermented milk (F.M.2). 
were detached by trypsin treatment and counted. The cells that remained attached to the flasks after washing were regarded as viable cells.

Cell titer 96 aqueous non-radioactive cell proliferation assay (MTS assay) Cells $\left(5 \times 10^{3}\right.$ cells) were suspended in $100 \mu \mathrm{l}$ of media in 96-well plates, to which $10 \mu \mathrm{l} /$ well of fermented or nonfermented milk which had been treated as previously described was added, and the plate was incubated at $37^{\circ} \mathrm{C}$. At 4,24 and $48 \mathrm{~h}$ after the start of incubation, $22 \mu \mathrm{l}$ of the MTS/PMS-solution (20:1, v/v) was added to each well, the incubation was continued for $4 \mathrm{~h}$, and then the absorbance at $490 \mathrm{~nm}$ of the solution in each well was measured using a micro-plate reader (BioRad, Model 450). The absorbance has been confirmed to be correlated with cell viability (Barltrop \& Owen 1991; Tada et al. 1986).

Morphological examination HL-60 cells incubated for
$48 \mathrm{~h}$ in the presence or absence of fermented milk (F.M.2) were observed under a light microscope.

Analysis of DNA fragmentation HL-60 cells $\left(5 \times 10^{5}\right.$ cells $/ 200 \mu \mathrm{l}$ ) cultured for $12 \mathrm{~h}$ and $24 \mathrm{~h}$ in the absence or presence of fermented milk (F.M.2) were supplemented with $10 \mu 1$ of $10 \mathrm{mg} / \mathrm{ml}$ proteinase $\mathrm{K}, 10 \mu 1$ of $10 \mathrm{mg} / \mathrm{ml} \mathrm{RNase} \mathrm{A}$, and $20 \mu \mathrm{l}$ of $10 \%$ SDS and incubated at $37^{\circ} \mathrm{C}$ for $30 \mathrm{~min}$. Three hundred microliters of NaI solution containing $6 \mathrm{M}$ NaI, 13 mM EDTA, $0.5 \%$ sodium $\mathrm{N}$-lauroyl sarcosinate, 10 $\mathrm{mg} / \mathrm{ml}$ glycogen, and $20 \mathrm{~mm}$ Tris- $\mathrm{HCl}, \mathrm{pH} 8.0$, was then added to each culture. After incubation at $60^{\circ} \mathrm{C}$ for $15 \mathrm{~min}$, the cultures were mixed with $500 \mu 1$ of $100 \%$ isopropanol, and DNA fragments were prepared according to the procedure described by Ishizawa et al. (1991). The DNA fragments were loaded onto a $1.5 \%$ agarose gel in TBE buffer $(89 \mathrm{mM}$ Tris, 89 $\mathrm{mM}$ boric acid, and $2 \mathrm{mM}$ EDTA) and electrophoresed at a

\section{DLD-1}

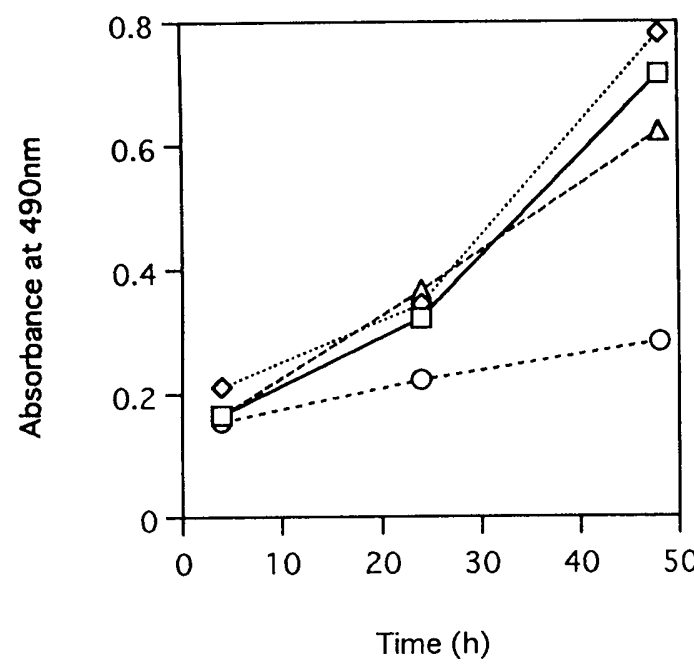

HL-60

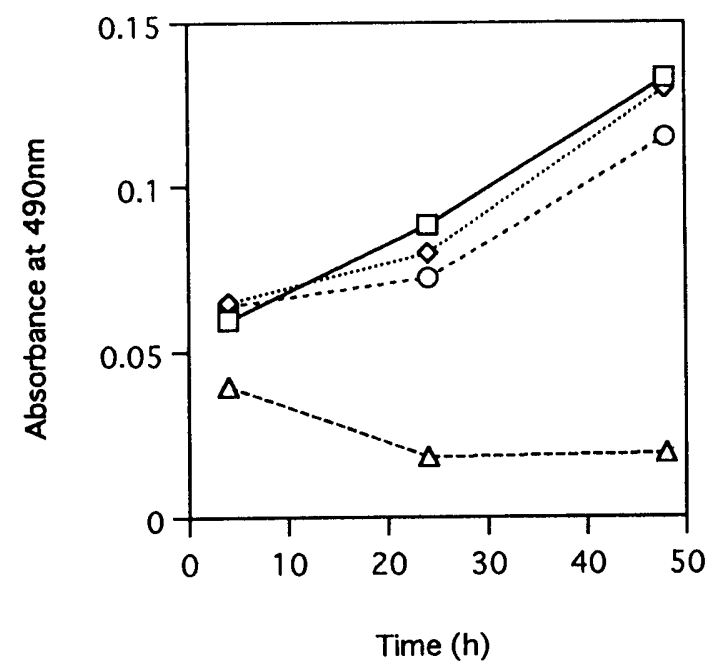

$\mathrm{MKN}-1$

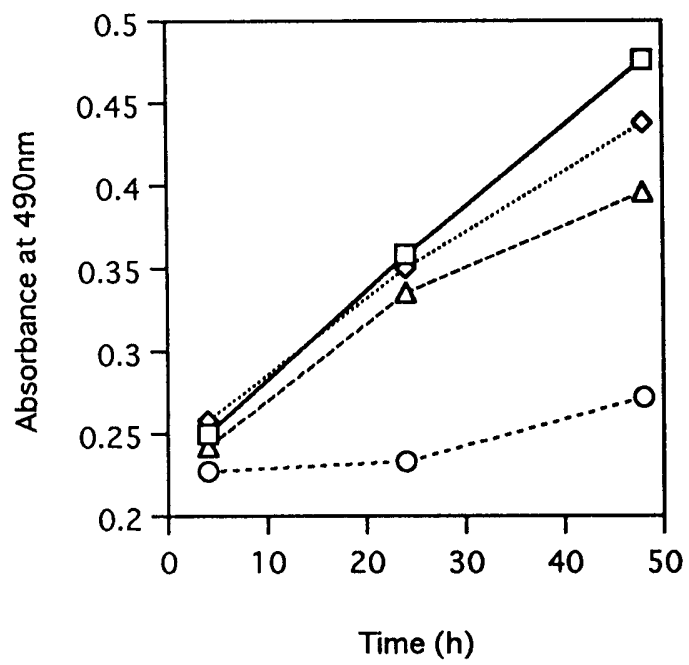

$\mathrm{Fb}$

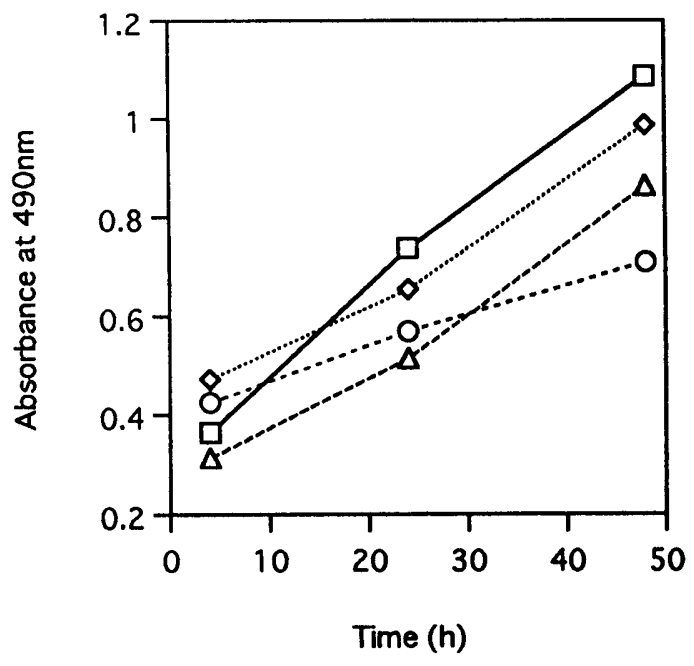

Fig. 2. Effects of milk on the proliferation activity of human transformed and nontransformed cells measured by the MTS assay. Human cells were cultured in the absence or presence of fermented or nonfermented bovine milk. At 4, 24, and $48 \mathrm{~h}$ after the start of culture, the MTS/PMS-solution was added. After a further incubation for $4 \mathrm{~h}$, the absorbance at $490 \mathrm{~nm}$ was measured. The symbols are the same as those in Fig. 1. 
constant voltage of $100 \mathrm{~V}$. The gel was stained with ethidium bromide and photographed on a UV transilluminator.

\section{Results and Discussion}

The sensitivities of human carcinoma cells and normal cells to the nonfermented and two kinds of fermented bovine milk were assayed. Figure 1 shows the number of viable cells which proliferated in the presence and absence of the milks. The fermented milk cultured with various lactic acid bacteria and a yeast (F.M.1) exhibited strong proliferation inhibition activity toward two cell lines, DLD-1 and MKN-1. In contrast, the effect of this fermented milk on the proliferation activity of HL- 60 cells was the same as that of nonfermented bovine milk, suggesting that the sensitivity to this fermented milk is different among the cell lines, transformed cells and nontransformed cells. Almost the same results were observed using the MTS assay (Fig. 2). The fermented milk cultured with a single lactic acid bacterium, B. longum, and a yeast (F.M.2) exhibited marked proliferation inhibition activity toward HL-60 cells, but not toward the other cells tested. The inhibition of the proliferation activity of HL- 60 cells measured by the MTS assay also decreased with incubation time. That a viability decrease with culture time was specific to HL-60 cells suggested that HL-60 cells were likely to lyse by the F.M.2 during culturing. On the other hand, the

(A)

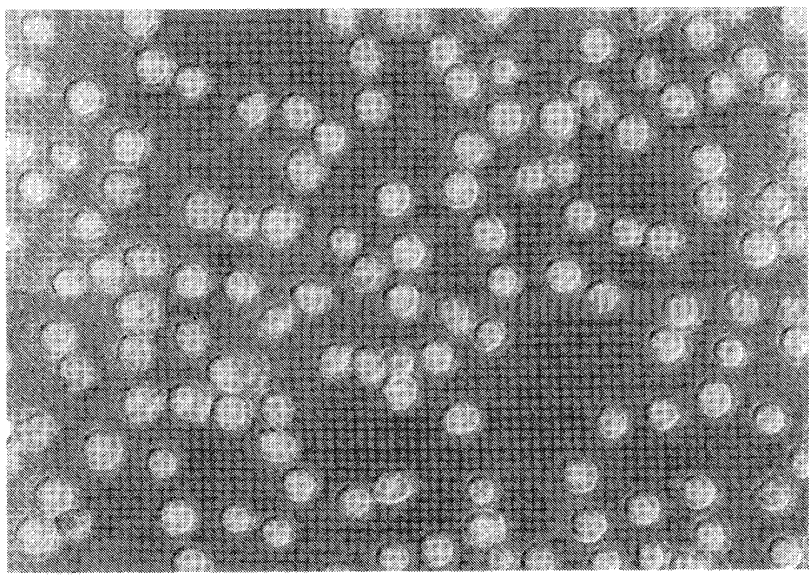

(B)

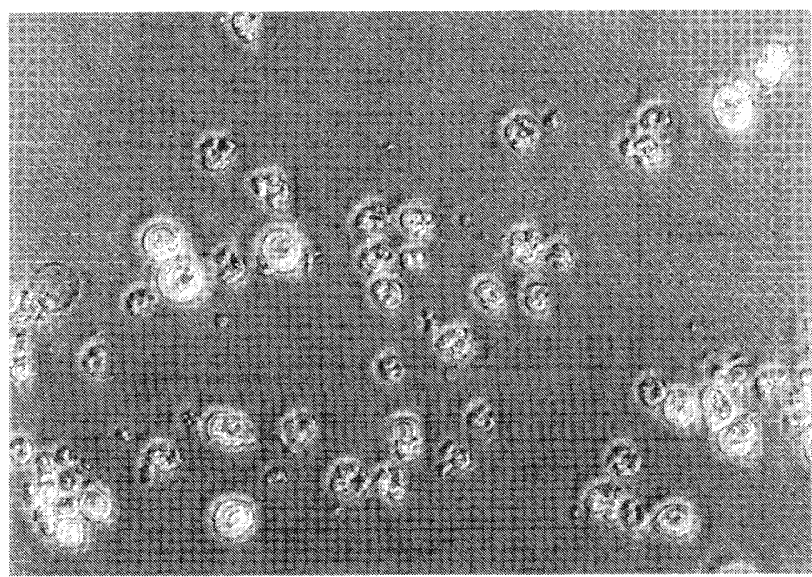

Fig. 3. Apoptosis in HL-60 cells induced by incubation with fermented milk (F.M.2). (A) Cells $24 \mathrm{~h}$ after incubation in the absence of milk. (B) Cells $24 \mathrm{~h}$ after incubation in the presence of fermented milk (F.M.2). nonfermented bovine milk exhibited a moderate proliferation inhibition activity toward the DLD-1 and HL-60 cells and a weak inhibition activity toward the MKN-1 and Fb cells, although the effect of nonfermented bovine milk on cell proliferation was much less when the activity was measured by the MTS assay. Recently, Hakansson et al. (1995) reported that a multimeric form of $\alpha$-lactalbumin present in human milk induces cell death in various cell lines in vitro. Our results suggest that bovine milk may also have a suppressive effect on the proliferation of certain cell lines.

While investigating the effect of fermented milk on the proliferation activity of cells, we observed morphological changes in HL-60 cells incubated with milk fermented by culturing with a mixture of $B$. longum and a yeast. Figure 3 shows the morphological change in HL-60 cells incubated for $48 \mathrm{~h}$ in the presence of F.M.2. The cells exhibited shrinkage and the formation of apoptotic bodies, which are compatible with the occurrence of apoptosis (Kerr et al. 1987). Untreated HL-60 cells maintained their normal morphology during the test period. The DNA of HL-60 cells was then examined. DNA fragmentation is known as a characteristic feature of apoptosis (Wyllie 1980; Vaux \& Strasser 1996). As shown in Fig. 4, oligonucleosome-length DNA fragments (DNA laddering), characteristic of apoptosis were observed in HL-60 cells incubated for $24 \mathrm{~h}$ in the presence of F.M.2.

The milk fermented with a single strain of lactic acid bacterium alone, such as Bifidobacterium longum, Lactobacillus delbrueckii subsp. lactis, Lactobacillus delbrueckii subsp. bulgaricus, Lactobacillus acidophilus, or Streptococcus salivarius subsp. thermophius had no significant effect on the proliferation of HL-60 cells (data not shown). Fermented milk products such as yogurt are commonly manufactured by fermentation within a day. In contrast, F.M.2 was prepared

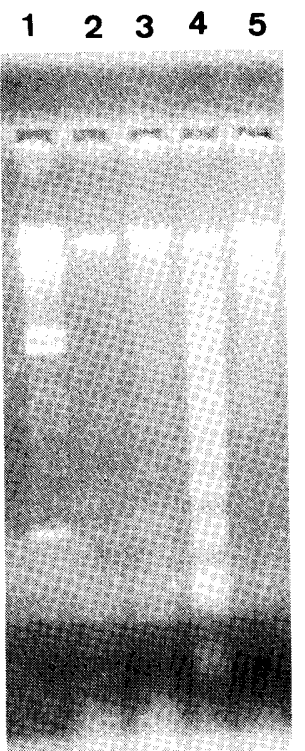

Fig. 4. Agarose gel electrophoresis of DNA extracted from HL-60 cells. Lane 1, molecular size markers. Lane 2, DNA from HL-60 cells cultured for $24 \mathrm{~h}$ in the absence of milk. Lane 3, DNA from HL-60 cells cultured $12 \mathrm{~h}$ in the absence of milk. Lane 4, DNA from HL-60 cells cultured $24 \mathrm{~h}$ in the presence of fermented milk (F.M.2). Lane 5, DNA from HL-60 cells cultured for $12 \mathrm{~h}$ in the presence of fermented milk (F.M.2). 
after a long incubation of over $14 \mathrm{~d}$, suggesting that autolysis of yeast cells will occur during incubation. This would lead to the participation of various intracellular enzymes of yeast in the fermentation of milk. On the other hand, raw bovine milk has not been reported to induce apoptosis in several cell lines (Hakansson et al. 1995). These observations, combined with our present results, indicate that bovine milk contains latent factors which can induce apoptosis in HL-60 cells and the factors would be produced from the milk by cooperative digestion of the milk components using enzymes from both microorganisms, B. longum and $S$. cerevisiae.

The tryptic hydrolyzates of bovine casein have been known to have various biological activities (Chiba \& Arai 1988). However, only a few experiments have been performed on the antitumor activity of fermented milk directly on cultured human cell lines. Biffi et al. (1977) reported that the milks fermented with $B$. infantis and $L$. acidophilus effectively inhibited the growth of MCF7 cells. Nagaune (1995) also described that tryptic peptide (P-10) from $\mathcal{x}$-casein exhibited proliferation inhibition activity in BALB/c3T3 cells in vitro. The milk fermented by a mixed culture with various lactic acid bacteria and a yeast (F.M.1) selectively exhibited proliferation inhibition activity toward two human carcinoma cell lines (DLD-1 and MKN-1), but not toward human leukemia HL-60. These results suggest that the cell proliferation inhibition substances derived from milk might be different between F.M.1 and F.M.2, and bovine milk must contain a wide variety of latent factors that regulate the proliferation of various types of animal cells. We are currently isolating and identifying the substances that induce apoptosis in HL-60 cells with a view toward clinical application of the factors.

\section{References}

Adachi, S., Itoh, T., Arihara, K. and Mukai, T. (1990). Ecology of lactic acid bacteria with special reference to Kefir-granule formation by Lactobacillus kefiranofaciens. Biseibutu, 6, 15-26 (in Japanese). Barltrop, J.A. and Owen, T.C. (1991). 5-(3-Carboxymethoxyphenyl)- 2-(4,5-dimethylthiazolyl)-3-(4-sulfophenyl)tetrazolium, inner salt (MTS) and related analogs of 3-(4,5-dimethylthiazolyl)-2,5-diphenyltetrazolium bromide (MTT) reducing to purple water-soluble formazans as cell-viability indicators. Bioorg. Med. Chem. Lett., 1. 615-618.

Biffi, A., Coradini, D., Larsen, R., Riva, L. and Fronzo, G. (1997). Antiproliferative effect of fermented milk on the growth of a human breast cancer cell line. Nutr. Cancer, 28, 93-99.

Ezzat, N., EL Soda, M., Bouillanne, C., Zevaco, C. and Blanchard, P. (1985). Cell wall associated proteinases in Lactobacillus helveticus, Lactobacillus bulgaricus and Lactobacillus lactis. Milchwissenschaft, 40, 140-143.

Hakansson, A., Zhivotovsky, B., Orrenius, S., Sabharwal, H. and Svanborg, C. (1995). Apoptosis induced by a human milk protein Pro. Natl. Acad. Sci. USA, 92, 8064-8068.

Chiba, H. and Arai, S. (1988). Physiological functional food. Kagaku to Seibutu, 26, 34-40 (in Japanese).

Ishizawa, M., Kobayashi, Y., Miyamura, T. and Matsuura, S. (1991). Simple procedure of DNA isolation from human serum. Nucleic. Acids Res., 19, 5792-5793.

Kerr, J.F.R., Searle, J., Harmon, B.V. and Bishop, C.J. (1987). In "Apoptosis in Perspectives on Mammalian Cell Death," ed. by C.S. Pottenn. Oxford Sci. Publ., Oxford, pp. 93-128.

Kok, J. (1990). Genetics of the proteolytic system of lactic acid bacteria. FEMS Microbiol. Rev., 87, 15-42.

Nagaune, S. (1995). Nyu Tanpakusitu Yurai Saibōkinō Tyosetu Bussitu no Kensaku to sono Sayōkisa no Kaimei. In "Kinosei Shokuhin no Kenkyu," ed. by S. Arai. Japan Scientific Societies Press, Tokyo, pp. 72-77 (in Japanese)

Pritchard, G.G. and Coolbear, T. (1993). The physiology and biochemistry of the proteolytic system in lactic acid bacteria. FEMS Microbiol. Rev., 12, 179-206.

Tada, H., Shiho, O., Kuroshima, K., Koyama, M. and Tsukamoto, K (1986). An improved colorimetric assay for interleukin 2. $J$. Immunol. Methods, 93, 157-165.

Tamai, Y., Oishi, H., Nakagawa, I., Watanabe, Y., Shinmoto, H., Kuwabara, Y., Yamato, K. and Nagai, S. (1995). Antimutagenic activity of the milk fermented by mixed-culture with various lactic acid bacteria and a yeast. J. Jpn. Soc. Food Sci. Technol., 42, 383387.

Vaux, D.L. and Strasser, A. (1996). The molecular biology of apoptosis. Proc. Natl. Acad. Sci. USA, 93, 2239-2244.

Wyllie, A.H. (1980). Glucocorticoid-induced thymocyte apoptosis is associated with endogenous endonuclease activation. Nature, $\mathbf{2 8 4}$, $555-556$. 